\title{
Primary peritoneal mucinous adenocarcinoma in a man
}

\author{
Fumiko Satoh ${ }^{1}$ and Yutaka Tsutsumi ${ }^{2}$ \\ ${ }^{1}$ Kitasato University School of Medicine \\ ${ }^{2}$ Pathos Tsutsumi
}

June 3, 2021

\begin{abstract}
A 69-year-old man suffered from lethal peritoneal carcinomatosis. At autopsy, no primary lesion was identified in the gastrointestinal, pancreatobiliary, respiratory, urinary and male reproductive organs. The tumor consisted of mucin-containing and gland-forming columnar cells with minimal nuclear atypia. The final diagnosis was primary peritoneal mucinous adenocarcinoma in a man.
\end{abstract}

\section{Hosted file}

Primary peritoneal mucinous adenocarcinoma-3.docx available at https://authorea.com/users/ 417873/articles/524803-primary-peritoneal-mucinous-adenocarcinoma-in-a-man

\section{Hosted file}

Figures 1-3.pptm available at https://authorea.com/users/417873/articles/524803-primaryperitoneal-mucinous-adenocarcinoma-in-a-man 